\title{
Bright idea
}

\author{
In today's era of start-ups, spin-offs and university-industry collaborations, it pays to be \\ knowledgeable about patents and how they can help.
}

Scientists are innovators, and those working in photonics are no exception. From Ted Maiman's demonstration of the first experimental laser in 1960 (see our obituary on page 372 for a look back at his achievements ${ }^{1}$ ) to the development of the LED and silicon-photonic technology, all of these breakthroughs are based on ideas with commercial significance and appeal — even though the inventors may not have seen this at first. But who protects or owns those ideas?

Protecting technical and scientific ideas can be complicated, and falls under the umbrella of patent law. A patent is a legal right granted by a patent office for a new invention. It usually belongs to the inventor unless he or she has given away the rights to someone else (for example, an employee's invention will often belong to the employer). The patent owner can then legally block others from using his or her idea for commercial purposes without permission.

Patents and intellectual property (IP) are becoming increasingly important in the modern scientific arena, but especially so in photonics, where so much of the research is motivated by the potential commercial applications of optical technology. Start-up companies rely heavily on patents to get their operations off the ground, using them to secure investment or a position in the market by shutting out competitors.

As the European patent attorney Andrew Fearnside explains in this month's Commentary ${ }^{2}$, a scientist who comes up with a new innovation can do a number of things: formally protect the idea (through patents, for example); enter into confidentiality agreements with collaborators; publicly disclose the information deliberately so others cannot lay claim to it; or do nothing. Doing nothing can actually help a new area of technology to flourish by encouraging the sharing of information and the establishment of

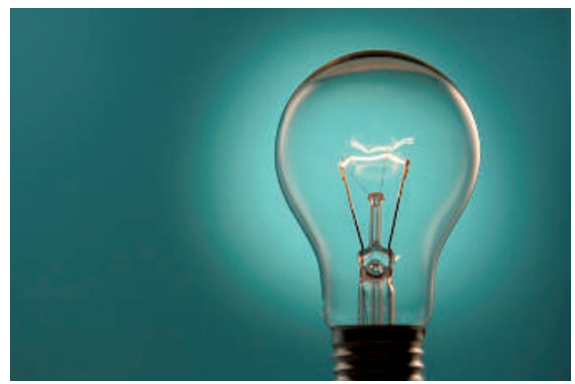

India are catching up. According to the World Intellectual Property Organization ${ }^{4}$, in 2006 six times more patent applications were filed in China than ten years previously.

Japan, a key hub for photonics, has the largest number of patents in force worldwide (when measured according to the country in which patent applicants live). As of 2004, people living in Japan had over 1.5 million patents in force. The government is keen to continue driving IP issues to the top of the agenda. As Prime Minister Junichiro Koizumi stated in 2002, Japan needs to become an 'intellectual property nation' if it is to succeed in the global economy ${ }^{5}$. There are now about 40 patent-licensing offices installed in Japan's universities, and universities are being given more freedom to keep the revenue from any IP they generate for themselves. In the corporate world, employee awareness of IP is growing too. In a landmark legal case in 2004, Shuji Nakamura, whose work at Nichia led to the development of the blue LED, took his ex-employer to court over what he felt was an insufficient amount of compensation for his ideas. The court awarded him $\$ 190$ million, although this sum was later reduced.

What is clear is that today's scientists have to be jacks-of-all-trades. Not only do they have to be good at science, but increasingly they must also be economically and commercially tuned in. As an innovator and scientist, the key is to be aware of the information you are creating, to realize that information is power and to decide how best to exercise that power. Intellectual property is something that a modern researcher cannot afford to ignore.

References

1. Hecht, J. Nature Photon. 1, 372-373 (2007).

2. Fearnside, A. Nature Photon. 1, 357-359 (2007)

3. Wyant, J. C. Nature Photon. 1, 301-302 (2007).

4. WIPO Patent Report (2006), <http://www.wipo.int/ipstats/en/ statistics/patents/patent_report_2006.html >.

5. Thomson Scientific 2007 Patent Focus Report, <http://scientific thomson.com/news/newsletter/2007-02/8361190>. 